\title{
Paradulichia spinifera Gurjanova, 1946 (Amphipoda, Dulichiidae), a valid species?
}

\section{Per-0tto Johansen' and Wim Vader ${ }^{2}$}

\begin{abstract}
Johansen P-O and Vader W. 2019. Paradulichia spinifera Gurjanova, 1946 (Amphipoda, Dulichiidae), a valid species? Fauna norvegica 39: 111-118.

Examination of Paradulichia-material collected from the Barents Sea during the Mareano cruises indicated that there are clear morphological differences between Paradulichia typica Boeck, 1871 from the Hardangerfjord, W. Norway and Paradulichia spinifera Gurjanova, 1946 from the Arctic. Based on our material and the original descriptions, these differences are the acute ventral parts of the body segments, the triangularly shaped coxal plates 3 and 4 , the shape and length of the mandible palp articles, the long merus of pereopods 5 and 6 , the elongate telson and the 2-articulate rami of uropod 2 .
\end{abstract}

doi: 10.5324/fn.v39i0.2993. Received: 2019-03-20. Accepted: 2019-06-18. Published online: 2019-07-11. ISSN: 1891-5396 (electronic).

Keywords: Paradulichia, Barents Sea, morphology.

1. Hauge, NO-5281 Valestrandsfossen, Norway.

2. Tromsø Museum - Universitetsmuseet, Universitetet i Tromsø, NO-9037 Tromsø, Norway.

Corresponding author: Per-Otto Johansen

E-mail:perotto.johansen@gmail.com

\section{INTRODUCTION}

The amphipod genus Paradulichia Boeck, 1871 is unique within the family Dulichiidae because of its rudimentary uropod 2. According to the latest revision of the family (Laubitz 1977) the genus has only a single species; P. typica Boeck, 1871. Two further species have been described in the genus; of these one, $P$. secunda Blake, 1927 from the US east coast, has been very imperfectly described, while the other one, $P$. spinfera Gurjanova, 1946 from the Russian Arctic was synonymized with P. typica by Laubitz (op. cit.). The present authors have examined fresh material from the Arctic regions of Norway, which cast doubt on this synonymy.

The descriptions of P. typica by Boeck (1871) and Sars (1894) are both based on adult females from the Hardangerfjord, SW Norway; Gurjanova's material came from the Russian Arctic, while it is not quite clear on what material Laubitz' illustrations were based. However, Laubitz mentions specimens from the Leningrad collection (ZI, three specimens from Russian Arctic). We have as yet been unable to ascertain whether P. spinifera type material exists in the collections of the St Petersburg museum. In our opinion, the differences in habitus of $P$. spinifera and $P$. typica are so conspicuous that a thorough examination of these was needed. Therefore, our comparisons of $P$. spinifera and $P$. typica are based on own figures of adult females of $P$. spinifera from the Arctic, in addition to the figures and text of P. typica from Boeck (1871, 1872/76) and Sars (1894). The descriptions that Gurjanova $(1946,1951)$ gave of $P$. spinifera, were based on material from stations in the Arctic Polar Basin $\left(78^{\circ} 4-80^{\circ} 5 \mathrm{~N}\right.$ and $34^{\circ} 0-$ $\left.142^{\circ} 1 \mathrm{E}\right)$. Our drawings and descriptions of $P$. spinifera have been made using three adult female specimens of $P$. spinifera collected in the eastern part of the Barents Sea.

\section{MATERIAL AND METHODS}

Since we did not succeed to obtain Paradulichia spinifera type material, our description is based on material collected in the eastern Barents Sea during the Mareano-cruises. The Mareanoproject maps depth and topography, sediment composition, contaminants, biotopes and habitats in Norwegian waters. The 
results of the surveys are available on the Mareano-website, visualised through maps (http://www.mareano.no/en/).

The collected material was initially fixed in $4 \%$ formalin and later transferred to $96 \%$ ethanol.

The total length of the analysed specimens was measured from rostrum to telson.

The animals were mounted on microscope slides in Faure's fluid. Stacks of photos were taken from a Bresser Biolux NG microscope with an electronic sensor and the drawings were made with an electronic pc-tablet using the techniques described by Coleman $(2003,2006,2009)$. The examined material is kept in the collections of the University Museum in Bergen, Norway.

\section{RESULTS}

\section{Systematics}

Order Amphipoda Latreille, 1816,

Family Dulichiidae Dana, 1849, Genus Paradulichia Boeck, 1871,

Diagnosis (Barnard \& Karaman 1991): Body cylindrical, smooth, pereon segments 1-2 short, last 2 pereon segments fused together; urosomites 2-3 coalesced, urosomite 1 very elongate. Rostrum short, ocular lobes obsolescent, blunt, antennal sinus weak. Eyes large. Antennae elongate, 1 longer than 2, both slender, peduncular article 3 of antenna 1 much longer than 1, peduncular articles 2-3 longest, accessory flagellum 3-5 articulate. Antenna 2 peduncular article 3 short, main flagellar articles very few. Epistome [? unproduced anteriorly]. Labrum broad, bilobed. Mandible normal, palp strong, very slender, article 3 rectolinear, shorter than 2. Labium with entire outer lobes, with well-developed inner lobes, mandibular lobes long, blunt. Inner plate of maxilla 1 triangular, large, without setae, outer plate with 9 spines, palp 2-articulate. Plates of maxilla 2 ordinary, inner plate slightly shortened, without mediomarginal setae. Inner plate of maxilliped with distal spines (fide Dr Laubitz but in illustrations appearing as setae), outer plate short, reaching halfway to apex of palp article 2 , with only spine-setae on medial margin, palp with 4 articles, article 2 long, article 3 unlobed, article 4 short, with long setae. Coxae very small, short, not contiguous, not spiniform, coxa 1 not dilated, not produced forward, coxa 4 not longer than coxa I, not lobed, coxa 5 somewhat longer than 4 , coxae 6-7 not smaller than anterior coxae. Gnathopods 1-2 of subequal size, small, both with sublinear articles, gnathopod 1 in male poorly subchelate, article 5 long, linear, unlobed, palm short, gnathopod 2 subchelate, article 5 slightly longer than 6 , poorly lobed, article 6 expanded. Pereopods 3-4 longer than gnathopods, similar, with slender article 2, article 4 dilated, dactyls short. Pereopods 5-7 similar to each other, scarcely progressively longer, not prehensile, with linear article 2, dactyls short, curved. Sternal processes of thorax absent. Coxal gills present on segments
2-5. Pleopods normal. Epimeron 3 not bisinuate (posteriorly ?). Uropod 1 biramous, rami slightly unequal, much longer than peduncle, peduncle without ventrodistal process; uropod 2 very small, with only 1 ramus or forming small leaf lacking rami. Uropod 3 absent. Telson entire, as long as broad, ovate.

Type species. Paradulichia typica Boeck, 1871.

\section{Paradulichia spinifera Gurjanova, 1946}

(Figures 1-3)

Paradulichia spinifera Gurjanova, 1946

Paradulichia spinifera Gurjanova, 1951

Paradulichia typica Laubitz, 1977

\section{Material examined}

Three adult females with oostegites, total body length, each

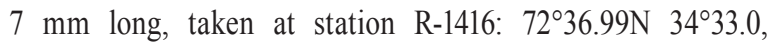
RP-sledge, 273 meter depth, 27 August 2014: ZMBN 130813A-D, ZMBN 130814-A-D and ZMBN 130815-A-B.

\section{Description, (ZMBN $130813(\alpha)$, ZMBN $130814(\beta)$ and ZMBN $130815(\mu))$.}

\section{Head:}

Eyes large and protruding. Rostrum broadly convex. Eye lobes forming a blunt angle. Both antennae with long setae along ventral margin. Antennae 1 and 2 shorter than the body. Antenna 1 longer than antenna 2.

Antenna 1, peduncle article 1 broader than and half the length of article 2, peduncle article 3 subequal to article 1 and 2 combined. Flagellum subequal to peduncle article 2, flagellum consisting of five articles where the first article is the longest. A few long setae on the margin of flagellum article 1 and between the successive articles. Accessory flagellum with three articles where the last article is very small.

Antenna 2, peduncle article 1-3 short and broader than article 4 and 5, peduncle article 4 and 5 subequal in length. Flagellum consisting of three articles and shorter than peduncle article 5. Flagellum article 1 subequal to the two successive articles combined.

Lower lip broad, bi-lobed. Inner lobes well developed, reaching almost to the upper margin of the outer lobes. The upper margins of inner and outer lobes with short setae.

Upper lip triangular.

Mandible. Incisor and lacinia mobilis dentate. Four serrate strong accessory spines. Molar tubercles robust. Mandible palp robust, the second palp article $2 \mathrm{x}$ the third article, third article subequal to the first article. Long setae on the second and third article. Third article curved with three apical setae.

Maxilla 1. Inner plate small and triangular. Outer plate with more than ten forked apical spines in addition to spinelike setae that are decreasing in length along medial margin. Palp with 
two articles, the second article with four apical spines and long setae on the distal margin.

Maxilla 2. Plates oval in shape. Outer plate with long apical setae, inner plate with apical and medial setae.

Maxilliped. Inner plate broad with six apical spines and setae along inner margin. Outer plate broad with spines and setae along inner margin. Outer plate reaching the middle of palp article 2. Palp article 2 with long setae along inner margin. Palp article 3 with parallel margins and long apical setae. Palp article 4 with two strong apical setae.

\section{Pereon:}

Pereon segments 1 and 2 shorter than the following pereon segments. Pereon segments 6 and 7 coalesced. The ventral parts of the pereon segments are bent on both sides, each forming an almost horizontal plate with acute processes. Gnathopods 1 and 2 similar in length and shorter than pereopods 3 and 4. Pereopods 5, 6 and 7 longest, successively increasing.

Gnathopod 1. Coxa triangular-oval. Carpus broad and longer than both basis and propodus. Ventral margin of carpus plumose, ventral and medial margin of propodus with long plumose setae. Dactylus curved with short setae on inner margin. Small distal notch on propodus. Dactylus with a slim medial spine.

Gnathopod 2. Coxa triangular-oval. Basis, carpus and propodus subequal in length. Carpus and propodus less setose than in gnathopod 1. Dactylus curved and with short setae on inner margin. Three spines and short setae on the ventral margin of propodus. There is a distal notch on the propodus. Dactylus with a slim medial spine.

Pereopod 3. Coxal plate 3 broadly triangular. Basis longer than merus and posterior side of basis convex. Carpus distally widening. Carpus and propodus subequal in length. Dactylus with a broad oval medial spine.

Pereopod 4. Coxal plate 4 broadly triangular. Basis longer than merus and carpus. Carpus longer than propodus. Dactylus with a broad oval medial spine.

Pereopod 5. Coxal plate 5 broadly triangular. Basis longer than merus. Carpus and propodus subequal. Merus longer than carpus and propodus combined. Setae on the margins of basis and merus. Margins of carpus with spines. Dactylus with a slim medial spine.

Pereopod 6. Coxal plate 6 oblong-triangular. Basis subequal to merus. Merus longer than carpus and propodus combined. Setae on the margins of basis and merus. Margins of carpus with spines. Dactylus with a slim medial spine.

Pereopod 7. Coxal plate 7 oval-triangular. Basis shorter than merus. Merus subequal to carpus and propodus combined. Setae on the margins of basis and merus. Margins of carpus with spines. Dactylus with a slim medial spine.

\section{Pleon:}

Pleon segment 3 subequal to pleon segments 1 and 2 combined. Between the pleopods on the ventral side of the pleon there is a tubercle, a circular elevation.

\section{Urosome:}

Urosome segment 1 strongly elongated. Uropod 3 not developed. Uropod 1 long, outer margin of peduncle with one row of small spines, distal part of inner margin of the peduncle with a few setae, rami longer than peduncle, inner ramus longer than outer. Each ramus with two spine rows.

Uropod 2, vestigial, with a 2-articulate ramus, which is longer than peduncle. The last article stretches far beyond telson.

Telson longer than broad. Upper part of telson elevated.

\section{DISCUSSION}

The descriptions of P. typica by Boeck (1871, 1872/76) and Sars (1894) were all based on 5-6 mm long adult females collected from the Hardangerfjord, SW Norway. Our examined $7 \mathrm{~mm}$ specimens from the eastern part of the Barents Sea were also adult females and should be directly comparable to Sars' and Boeck's descriptions. Since these examined specimens from the Barents Sea were recorded in the cold Arctic Basin and agreed largely with Gurjanova's description of the $8 \mathrm{~mm}$ specimen of $P$. spinifera from further east in the Russian Arctic, our drawings were used in the comparisons with P. typica. A review of the observed differences is given in Table 1.

The most pronounced differences which distinguish $P$. spinifera from $P$. typica are the acute ventral parts of the body segments, the triangularly shaped coxal plates 3 and 4 , the long merus of pereopods 5 and 6 , the elongate telson and the 2-articulate rami of uropod 2.

In the following, the corresponding traits in P. typica are given in parenthesis.

The frontal view of the rostrum is broadly convex and the lateral lobe of the head shows a concave antennal sinus (rostrum triangular; antennal sinus inconspicuous).

Antenna 1 peduncle article 2 is $2 x$ peduncle article 1 (almost $3 \mathrm{x}$ in P. typica).

The mouth parts are quite similar in the two species. There are a few differences, however. The mandible palp is less slender, and article 1 is longer (very slender, with shorter article 1).

Gnathopod 1 has a broader basis, which is subequal to the propodus (slim and longer than propodus). Both gnathopods 1 and 2 have a narrow incision on the distal part of the propodus, close to the attachment of the dactylus (not shown in drawings of $P$. typica, but may have been overlooked). Pereopods 3 and 4 have a characteristic flat broad spine on the dactylus, pereopods 1, 2, 5, 6 and 7 have a flat slim spine on the dactylus (spines not shown in drawings of $P$. typica).

Uropod 2 ramus has 2 articles, as described by Gurjanova (1946) for P. spinifera. The total length of uropod 2 varied somewhat in our material, but there were always 2 articles. Paradulichia typica shows only 1 article in the descriptions by Boeck (1872/76) and Sars (1894); the ramus was absent in 


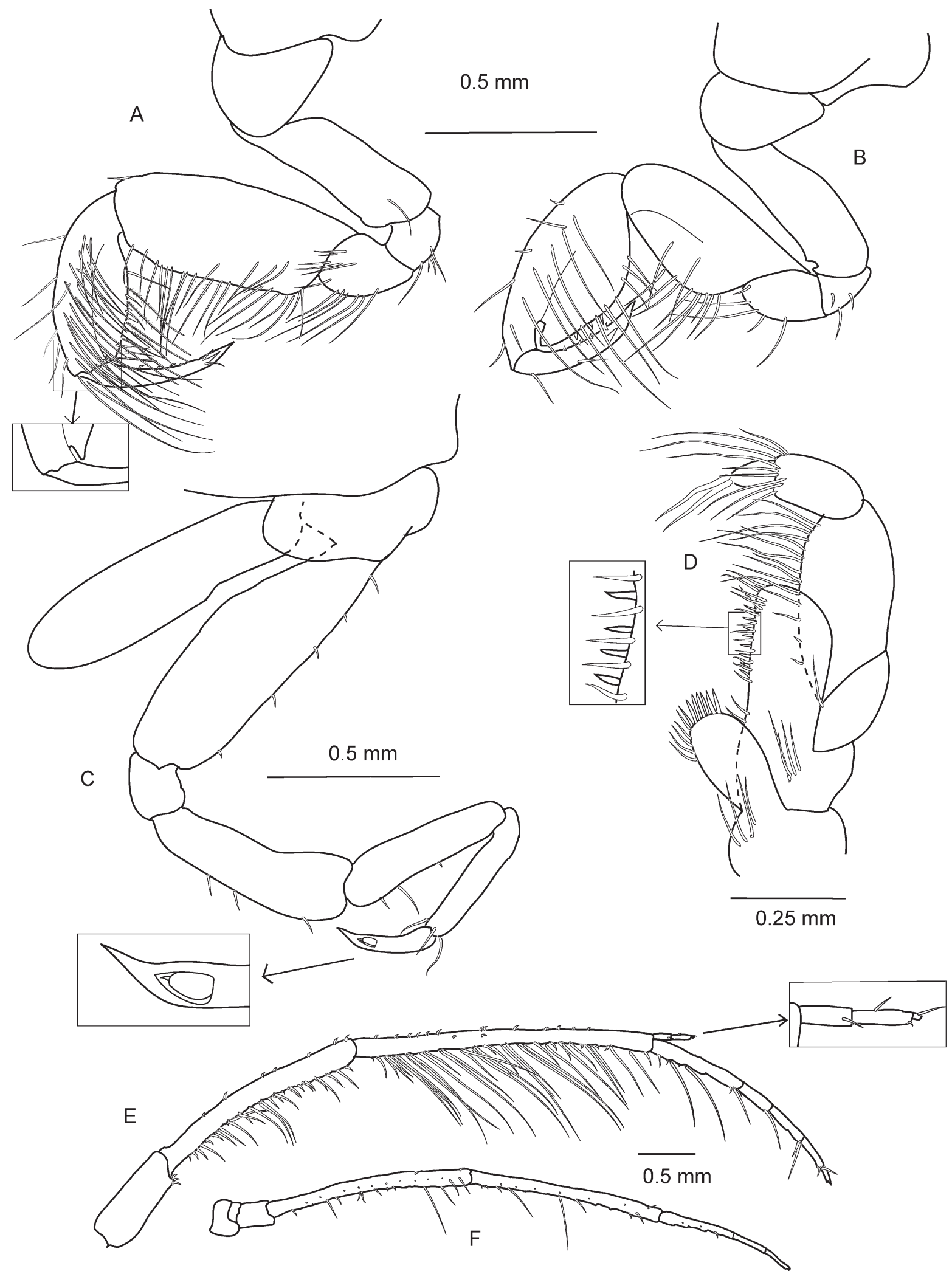

Figure I. Paradulichia spinifera. A. left gnathopod 1 (B); B. left gnathopod 2 ( $\beta$ ); C. right pereopod 3 with gill ( $\beta$ ); D. right part of maxilliped ( $\mu$ ); E. antenna $1(\beta)$; F. antenna $2(\beta)$. 


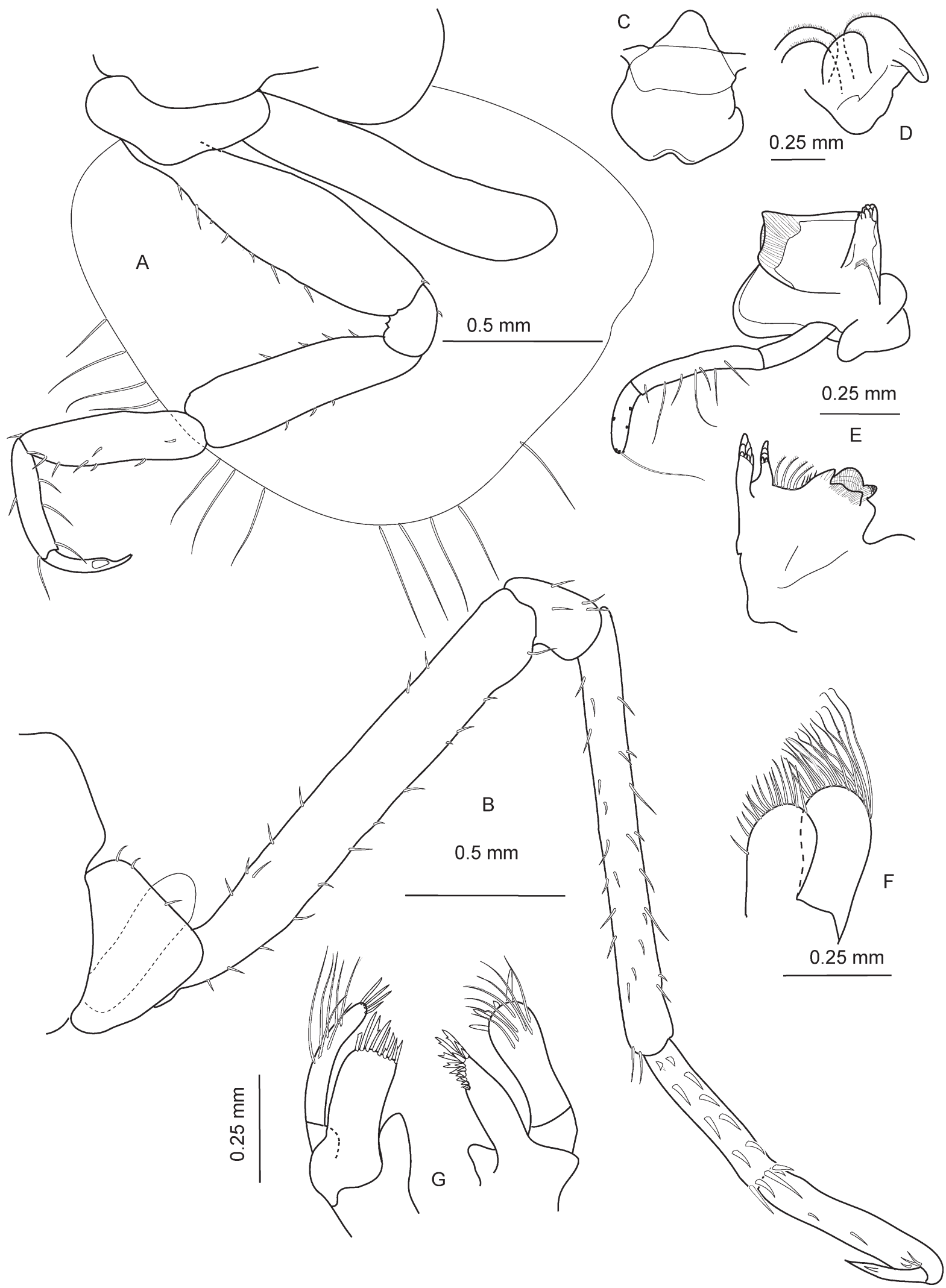

Figure 2. Paradulichia spinifera. A. left pereopod 4 with gill and oostegite (B); B. right pereopod 5 with gill (B); C. upper lip ( $\mu$ ); D. lower lip $(\mu)$; E. mandibles $(\mu)$; F. maxilla $2(\mu)$; G. maxilla $1(\mu)$. 


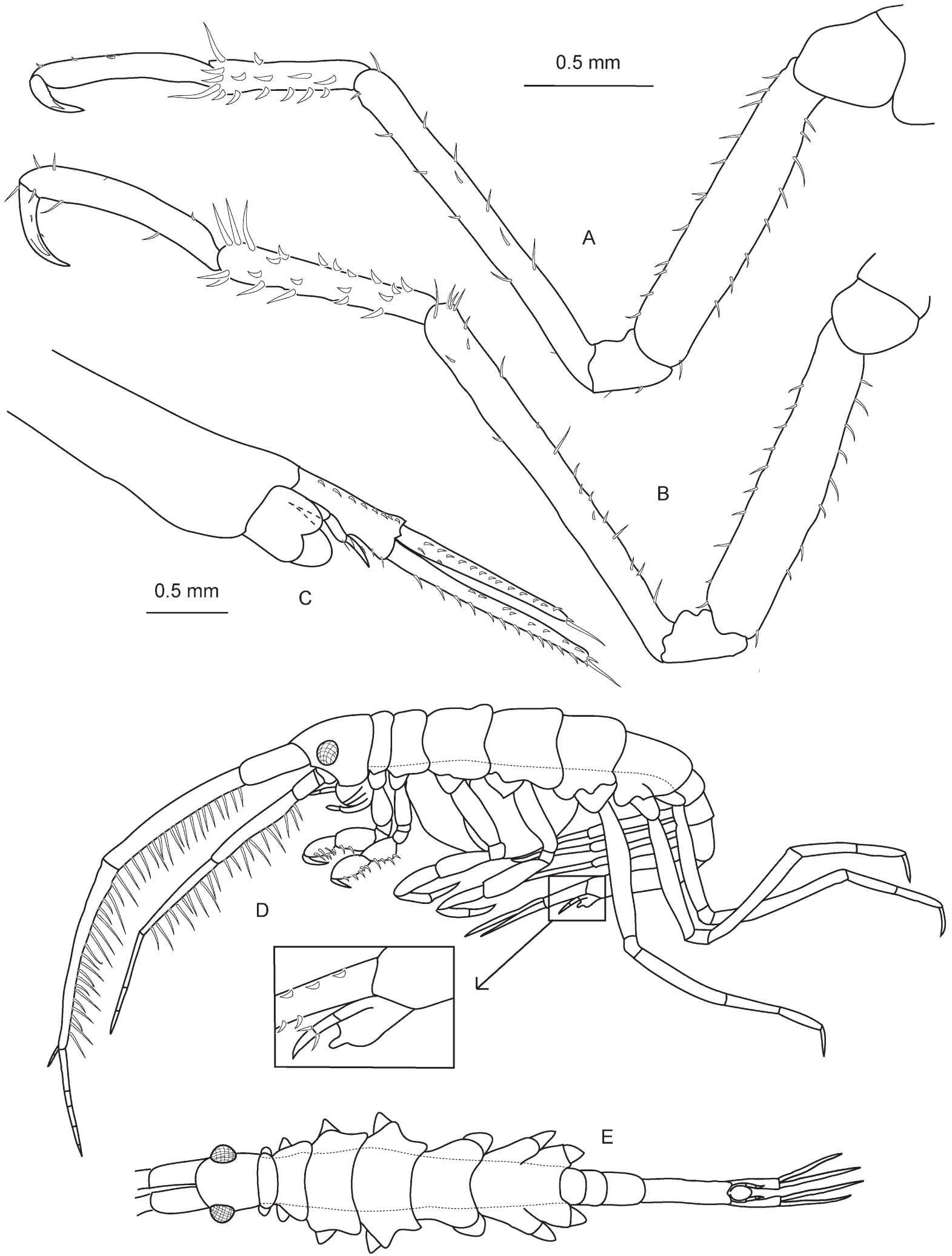

Figure 3. Paradulichia spinifera. A. right pereopod 6 ( $\beta$ ); B. right pereopod 7 ( $\beta$ ); C uropod 1, uropod 2 and telson ( $\alpha$ ). D. lateral view of female habitus; E. dorsal view of female habitus. 
Table I. Comparisons between Paradulichia spinifera and Paradulichia typica.

\begin{tabular}{|c|c|c|}
\hline Body part & P. typica, Boeck 1871 & P. spinifera, Gurjanova 1946 \\
\hline Rostrum & acute & broadly convex \\
\hline Eye lobe & slightly curved, no antennal 2 sinus & blunt angle, concave antennal 2 sinus \\
\hline Antenna 1 & peduncle article 2 nearly $3 x$ the length of article 1 & peduncle article $22 x$ the length of article 1 \\
\hline Lower lip & inner plates reaching $2 / 3$ of outer plates & inner plates reaching $3 / 4$ of outer plates \\
\hline Mandible palp & $\begin{array}{l}\text { Palp especially thin, article } 32 x \text { the length of article } \\
\text { 1. Article } 3 \text { rectolinear. }\end{array}$ & $\begin{array}{l}\text { Palp broader, article } 3 \text { subequal to article } 1 \text {. Article } \\
3 \text { curved. }\end{array}$ \\
\hline Maxilliped & Palp article 3 distally widening & Palp article 3 with parallel margins. \\
\hline Pereon & Ventral parts of body segments smooth. & $\begin{array}{l}\text { Ventral parts of body segments horisontally bent, } \\
\text { forming a distally acute plate. }\end{array}$ \\
\hline Coxal plates 3 and 4 & rectangular & triangular \\
\hline Gnathopod 1 basis & slim and longer than propodus & broad and subequal to propodus \\
\hline Gnathopods 1 and 2 & - & Distal notching on propodus \\
\hline Pereopods 1-7 & - & Spine on dactylus \\
\hline Pereopod 4 carpus & $\operatorname{slim}$ & broader \\
\hline Pereopods 5 and 6 merus & subequal to carpus and propodus combined & longer than carpus and propodus combined \\
\hline Pleon & - & Ventral abdominal tubercles \\
\hline Uropod 2 & $\begin{array}{l}\text { Ramus with one article, article subequal to basal } \\
\text { segment }\end{array}$ & $\begin{array}{l}\text { Ramus with two articles, articles combined longer } \\
\text { than basal segment. }\end{array}$ \\
\hline Telson & length equal to width & longer than broad \\
\hline
\end{tabular}

all the specimens studied by Laubitz (1977) from southern Norway; this author found considerable individual variety in the development of uropod 2 in specimens from the NW Atlantic. The geographical position of Laubitz' drawing of Paradulichia was not given and it resembles P.spinifera more than P.typica. The observed variations she found may be due to geographically separated populations.

Gurjanova (1946) mentioned that antenna 1 of $P$. spinifera has a flagellum with 7 articles and an accessory flagellum with 5 articles. The flagellum in the specimen we examined had 5 articles and accessory flagellum with 3 articles. The number of articles may vary with the size of the specimens as it is seen in other amphipod species. The number of articles on flagellum on antenna 2 of Gurjanova's description agrees with our observations.

Gurjanova (1951) mentions the lack of spines on uropod 1 peduncle margin and used this as a defining character; in our specimens we observed small tight spines along the outer margin of uropod 1. Laubitz (1977) also observed spines on her specimens from the Arctic.

Gurjanova (1951) found a ventrally situated tubercle between each pair of pleopods. This was also observed on our specimens from the Arctic, but this was not mentioned by Boeck (1871, 1872/76) or Sars (1894) on P. typica.

Our examination indicates that there are clear morphological differences between $P$. typica from the Hardangerfjord and $P$. spinifera from the Arctic; in our opinion sufficient to consider $P$. spinifera to be a valid species. The question whether $P$. typica and $P$. spinifera are really two separate species and whether there may be a further species in the NW Atlantic (P. secunda?) should be finally decided by the use of molecular identifications of Paradulichia populations from its entire area of distribution. Molecular identification of this material is not possible, due to the conservation methods used.

\section{ACKNOWLEDGEMENTS}

We thank Børge Holte at the Institute of Marine Research/ Mareano-project and Jon Kongsrud at the University Museum in Bergen for the loan of the material used for the descriptions in this publication.

\section{REFERENCES}

Barnard JL, Karaman GS. 1991. The families and genera of marine gammaridean Amphipoda (except marine gammaroids). Records of the Australian Museum, Suppl 13, (Parts 1 and 2): $1-417,419-866$.

Boeck A. 1871. Crustacea Amphipoda Borealia et Arctica. Forhandlinger i Videnskabs-Selskabet i Christiania 1870, 83 280.

Boeck A. 1872/1876. De Skandinaviske og Arktiske Amphipoder. (1. and 2. Part). Printed A.W. Brøgger, Christiana.

Blake CH. 1927. New Crustacea from the Mount Desert Region, 
Maine. In: Biological Survey of the Mount Desert Region. Pt. 3. W. Procter (ed.) Wistar Institute, Philadelphia. Pp. 1 - 34 .

Coleman CO. 2003. "Digital inking": How to make perfect line drawings on computers. Organisms. Diversity \& Evolution 3 Electr. Suppl. 14: 1 - 14.

Coleman CO. 2006. Substituting time consuming pencil drawings in arthropod taxonomy using stacks of digital photographs. Zootaxa 1360: $61-68$.

Coleman, CO. 2009. Drawing setae the digital way. Zoosystematics and Evolution 85 (2): 305 - 310. doi: 10.1002/zoos.200900008

Gurjanova EF. 1946. New species of Isopoda and Amphipoda from the Arctic Ocean. Trudy drift. Exped. Icebreaker 'G.Sedov' 1937 - 1940. Ed. By Capt. V.K. Buinitski. Izdatelstvo Glavsevmorputi, Moscow.Leningrad. Vol.3 Pp. 272-297. (In Russian).

Gurjanova EF. 1951. Bokoplavy Morei SSSR i Sopredel'nykh Vod. (Amphipoda-Gammaridea). Izd. Akademia Nauk SSSR, Moscow \& Leningrad. (In Russian).

Laubitz, DR. 1977. A revision of the genera Dulichia Krøyer and Paradulichia Boeck (Amphipoda, Podoceridae). Canadian Journal of Zoology. 55(6):942 - 982.

Sars GO. 1894. An account of the Crustacea of Norway. Vol. 1. Amphipoda. Alb. Cammermeyer Forlag, Oslo and Copenhagen 1895.

Editorial responsibility: Anne Helene Tandberg.

This article is open-access and distributed under the terms of the Creative Commons Attribution 4.0 International license. This permits all non-commercial use, distribution, and reproduction in any medium, provided the original work is properly cited.

(http://creativecommons.org/licenses/by/4.0/). 